\title{
"The Coattail-Effect" in the Concurrent Elections in Indonesia: Study on Increasing Turnouts and Use of Voting Rights in the 2019 Elections
}

\author{
Nur Hidayat Sardini ${ }^{1}$, Dewi Erowati ${ }^{2}$ \\ \{nhsardini@live.undip.ac.id ${ }^{1}$,dewierowati@yahoo.com ${ }^{2}$ \} \\ Universitas Diponegoro, Indonesia ${ }^{1,2}$
}

\begin{abstract}
In-depth research on the "coattail effect" in the exertion of elections in Indonesia has never been conducted comprehensively. Compared to other countries such as the United States, some Latin American and Western European countries, which already have had experience holding concurrent elections, the phenomenon of concurrent elections in Indonesia is relatively anew as it was just conducted for the first time in 2019. This study aims to seek and explain the coattail effect in concurrent elections in Indonesia by finding the relations between two major elections, namely the presidential and legislative elections, with the increasing level of voter turnout and the level of the use of voting rights in polling stations in the 2019 elections. By using quantitative methods and analysis of the relations through Structural Equation Modeling, this study involves 438 respondents who were randomly drawn in 38 districts/cities from 7 provinces in Indonesia, which is the unit of analysis in this study. This study reveals that the increase of the turnout of the election in 2019 is due to the competitiveness of the presidential election rather than other major elections held concurrently. This study filled the vacuum of research rubric on the theory of coattail effect in the practice of election in Indonesia.
\end{abstract}

Keywords: Coattail-Effect, Concurrent Elections, Voter Turnouts, Voting Rights.

\section{Introduction}

The exertion of the 2019 concurrent election has become a new phenomenon and experience in the development of the electoral democracy of Indonesia. The people coming and exercising their voting right at the polling station on the $17^{\text {th }}$ April 2019, received 5 (five) types of the ballot paper. The first ballot is to vote for the president and vice president; the second ballot is to vote for the national parliamentary members; the third ballot is to vote for the regional representative board; the fourth ballot is to vote for the province parliamentary members; and the fifth ballot is to vote for the city/regency parliamentary members. In the practice of electoral democracy of Indonesia, the first one is usually referred to as the presidential election while the other four were referred to as the legislative election. In the past circumstances, especially the post-Suharto era, the presidential and legislative elections were held separately with a period of three months between one and the other.

The 2019 concurrent election of Indonesia contests 2 (two) candidates, the incumbent Joko Widodo (Jokowi) and his rival on the previous election Prabowo Subianto. On the other hand, the legislative election, at all levels, contests 245.000 people struggling to obtain 20.500 
legislative chairs spreading throughout 34 provinces in Indonesia. As his supporting parties, Jokowi has Indonesia Democratic Party of Struggle (PDI-P), Golkar Party, United Development Party (PPP), National Democratic Party (Nasdem), National Awakening Party (PKB), People's Conscience Party (Hanura), and Indonesia Justice and Unity Party (PKPI) at his side. However, Prabowo Subianto is supported by his party, Great Indonesia Movement Party (Gerindra), Prosperous Justice Party (PKS), National Mandate Party (PAN) and Democratic Party (Demokrat).

Looking at the phenomena of concurrent elections in the US, some Latin American and Western European countries, it shows a positive effect on the increase of voter turnout. The positive effect is in the form of political thrust to come to the polling stations to exercise their voting right at the D-day of the election [1]. This positive effect comes from the assumption that the popularity of the President and/or Vice President Candidate encourages the political participation of the people to also vote for legislator candidates from political parties supporting particular presidential candidate as the exertion of the president and legislative election is held concurrently at the same day [2][3]. Voters' stimulation is one of the aspects in the "coattail effect" theory about voters to attend and use their voting rights at the polling stations, which is nothing but motivating voters so that they participate in voting, until finally choosing a pair of presidential and vice presidential candidates the popular president [4]. With the assumption, this study aims to explain the coattail effect by finding the relations between the exertion of the first concurrent elections in Indonesia and the reason behind the increasing turnout voters in the elections.

\section{Methodology}

This study utilizes the quantitative method through the exercise of numerical data and objective result measurement by the use of statistical analysis. The purpose of this research is to unfold the relations between the popularity of President and Vice President Candidates on the encouragement of the voters to come and exercise their voting right at the polling stations, while the drive to attend motivates voters to increase political participation in elections. The measurement consists of two steps. Firstly, the sample is collected at 438 polling stations out of 810.329 polling stations spread throughout Indonesia [5], as well as a unit of analysis in this study. The sample is collected randomly at 438 polling stations in 37 regencies/cities and 7 provinces by voluntary students of Political and Government Department, Political and Social Science Faculty Universitas Diponegoro, Semarang. The voluntary students are enrolled in the course of the Planning and the Practice of Research at even semester year 2019/2020. The respondents are the voters coming and exercising their voting right at the polling station at the D-day of elections. Furthermore, the respondents are asked to answer the questionnaires which had been prepared beforehand. Each respondent was chosen based on the proportion of the number of voters in each polling station. After being answered and collected, the data is processed by utilizing the analysis of Structure Equation Model (SEM) and Partial Least Square (PLS) [6]. Secondly, the increase of turnout voters coming to exercise their voting right at the polling station could referred to the official data of the General Election Committee (KPU) becomes the means of data verification. 


\section{Discussion}

First, Respondents Profile. The research respondents consist of 438 people with the profile depiction as such. (i) Gender, 231 males (53,7\%) and 207 females (47,3\%); (ii) Age, the most respondents are those at 21-30 with the percentage of 25,1\%, and the least respondents are those more than 61 years old with the percentage of 3,9\%; those among them are those at 31-40 with $24,2 \%$, those at $41-51$ with $14,2 \%$. (iii) Education, with $53,7 \%$ the majority of the respondents are the graduate of senior high school while the minority of the respondents are the graduate of elementary school with $6,8 \%$; the others are those graduates of University with $29 \%$ and junior high school with 10\%. (iv) Employment, the respondents are mostly entrepreneurs with 37\% and the least respondents are farmer and the village functionaries with the percentage of $0.9 \%$; the others are civil servants with $6,2 \%$, teachers or lecturers with $4,6 \%$, labors, and housewives with $8,2 \%$, retired of civil servants with $2,5 \%$, students with $10,7 \%$, unemployed with $8,2 \%$ and others with $3 \%$.

Second, The popularity of President and/or Vice President Candidates. 90,9\% of respondents witness that after obtaining the ballot paper and entering the voting cubicle, they directly vote the president and vice president. The order of their vote is (i) President candidate (89\%); (ii) national parliamentary member candidate (3,2\%); (iii) regional representative board candidate $(0,9 \%)$; (iv) province parliamentary member candidate $(2,7 \%)$; and (v) regency/city parliamentary member $(2,7 \%)$. It is also shown that the consideration behind the vote for president and vice president candidates are (i) as a pair of candidates $(78 \%)$; (ii) merely favor on the president candidate (11\%); (iii) merely favor on the vice-presidential candidate $(2,1 \%)$. Furthermore, $41 \%$ of respondents believe that the presidential election is more necessary than the legislative election because the candidates of the president and vice president are more popular compared to the candidates of national and regional parliamentary member candidates $(52 \%)$.

Third, The motivation behind the exercise of voting right. Nearly all respondents $(99,1 \%)$ confess that the reason behind their political participation is coming from the conscience thrust, while $0,5 \%$ confess contradictorily and $0,2 \%$ confess that they did not come to exercise their voting right. Furthermore, the internal factors are believed to be their consideration to participate in the election (84\%) rather than external thrust. The respondents state that their political motivation arise because political participation in general election is perceived as an ideal role model of a good citizen $(74,4 \%)$, comprehending that one vote determinates the result of the election $(13,5 \%)$, assumption that voting is better than not voting $(9,4 \%)$ and consideration of voting as a part of worship $(1,6 \%)$. Although the majority of respondent's state that internal factors are more determinant than external factors, this study does not neglect the external factors affecting the political participation of the respondents. It is revealed that their political participation is encouraged by family, neighbor, and/or co-workers $(63 \%)$, the order of their superordinate affiliated politically with certain election participant $(2,5 \%)$, rewards or promises in the form of money, goods, or employment promise from the election participants or other parties $(2,7 \%)$.

Fourth, Turnout and the voting right exercise level on the D-day of Election. Nationally, the turnout of 2019 concurrent election reaches $81,77 \%$ which is an increase of $5 \%$ compared to the previous election in 2014 reaching only 77,5\%. This number, however, surpasses the expectation of the General Election Committee targeting only 77,5\%. The increase of the turnout in the 2019 concurrent election is encouraged by the voters' desire to get involved in the process of election. National political constellation towards the election politically demarcates Indonesian people to be in two strongholds, the incumbent supporters with the issues of 
nationalism, pluralism, anti-radicalism and the rival supporters identified with the issues of sectoralism in political identity. Each stronghold does not only hope for the victory of their supported candidates but also struggles to seize the victory of their supported candidates. At this election, the role of media, with any type of platform such as print and electronic, especially social media has successfully dramatized the political dynamics of the election. This circumstance encourages awareness of the exertion of the concurrent election of 2019. In every polling station, there found an increase of $6 \%$ to $7 \%$ of the turnout [5]. This turnout increase occurred since the increase of importance to vote for their supported president and vice president candidate since it is the only way to seize their victory and to conserve what has been developed and nurtured by the incumbent.

\section{Conclusion}

The concurrent election 2019 has proved the coattail effect as it has been experienced by some mature democratic country holding two or more major election at the same time. The effect proven by this research is the strengthening of the desire of the voters to come to the polling station and exercise their voting rights. The reason behind this political desire is the importance of the presidential election since $89 \%$ of respondents confess that they directly vote for the president and vice president after being given the ballot paper, implying that presidential election is more significant than the legislative election at all levels. Their motivation for participating in the election is encouraged by two factors, internal and external. This study reveals that the internal factor is more determinant than the later one. Among 428 polling stations in 37 regencies/cities of 7 different provinces, utilized as the research object, it is shown that the political participation increases between $60-70 \%$. The motivation behind their political awareness to come at the polling stations and exercise their voting rights is encouraged primarily by the importance of seizing the victory of their supported president and vicepresidential candidate. This awareness is also triggered by the strong assumption among the voters that the only means to seize the victory of their supported presidency candidates and to prevent the rival to come into power is to get themselves involved in the practice of concurrent election.

\section{References}

[1] M. Tavits, "Direct presidential elections and turnout in parliamentary contests," Polit. Res. Q., vol. 62, no. 1, pp. 42-54, 2009.

[2] A. Leininger, L. Rudolph, and S. Zittlau, "How to Increase Turnout in Low-Salience Elections: Quasi-Experimental Evidence on the Effect of Concurrent Second-Order Elections on Political Participation," Polit. Sci. Res. Methods, vol. 6, no. 3, pp. 509-526, 2018.

[3] S. F. Anzia, "Election timing and the electoral influence of interest groups," J. Polit., vol. 73, no. 2, pp. 412-427, 2011.

[4] G. Zudenkova, "A political agency model of coattail voting," J. Public Econ., vol. 95, no. 1112, pp. 1652-1660, 2011.

[5] KPU, Laporan Penyelenggaraan Pemilu Tahun 2019. Jakarta: KPU RI, 2019.

[6] J. F. Hair Jr, G. T. M. Hult, C. Ringle, and M. Sarstedt, A primer on partial least squares structural equation modeling (PLS-SEM). Sage publications, 2016. 